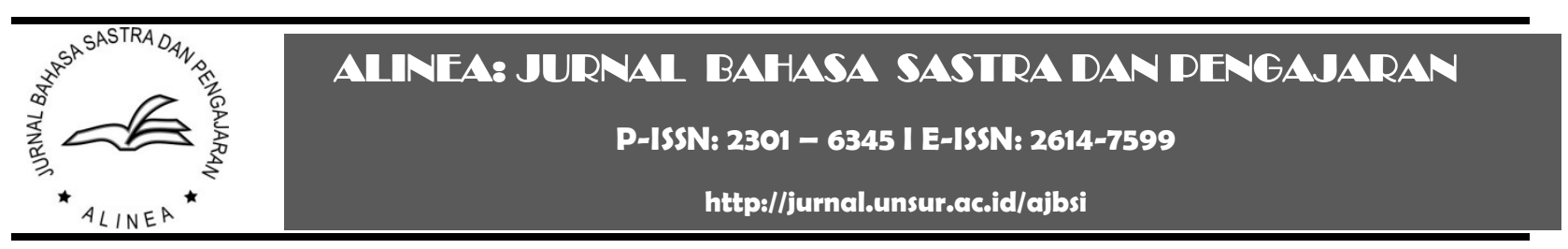

\title{
EFEKTIVITAS PEMBELAJARAN DARING DAN LURING DI SMP NEGERI 3 PLERET
}

\author{
Silvia Indah Sari, Dindi Fatika Sari \& Iis Suwartini \\ Universitas Ahmad Dahlan, Indonesia
}

Riwayat artikel:

Dikirim: 30 Nopember 2020

Direvisi: 4 Agustus 2021

Diterima: 5 Agustus 2021

Diterbitkan: 31 Oktober 2021

\section{Katakunci:}

proses, belajar, daring, luring

Keywords:

process, learn, online, offline

Alamat surat

silvia1700003020@webmail.uad.ac.id

\begin{abstract}
Abstrak:
Penelitian dilatarbelakangi oleh sistem pembelajaran daring dan lurimg yang diterapkan di SMP Negeri 3 Pleret. Tujuan penelitian yaitu untuk mengetahui keefektifan pembelajaran daring dan luring di SMP Negeri 3 Pleret. Penelitian dilakukan dengfan menggunakan pendekatan kualitatif dan metode wawancara. Hasil dari penelitian menunjukkan 69,2 siswa berpendapat bahwa pembelajaran luring lebih efektif, sedangkan 30,1 siswa berpendapat sebaliknya. Begitu juga pendapat guru, sebanyak $62 \%$ menyatakan bahwa pembelajaran luring lebih efektif dibandingkan dengan pembelajaran daring. Proses pembelajaran daring dilakukan dengan menggunakan aplikasi WhatsApp grup, Google Formulir dan lainnya. Tatap muka dilakukan seminggu 2 kali untuk mengumpulkan tugas, modul, dan lainnya. Model pembelajaran yang digunakan yaitu model pembelajaran "discovery learning”. Model tersebut dimaksudkan agar siswa menjadi aktif dan tanggap dalam mengikuti proses pembelajaran. Media yang digunakan yaitu "Powtoon" serta media lain seperti Power Point dan Word Dokumen.
\end{abstract}

\section{Abstract:}

The background of the research is the online and offline learning system implemented at SMP Negeri 3 Pleret. The purpose of the study was to determine the effectiveness of online and offline learning at SMP Negeri 3 Pleret. The research was conducted using a qualitative approach and interview methods. The results of the study showed that 69.2 students thought that offline learning was more effective, while 30.1 students thought otherwise. Likewise, the opinion of teachers, as many as $62 \%$ stated that offline learning was more effective than online learning. The online learning process is carried out using the WhatsApp group application, Google Forms, and others. Face-to-face meetings are held twice a week to collect assignments, modules, and more. The learning model used is the "discovery learning" learning model. The model is intended so that students become active and responsive in following the learning process. The media used is "Powtoon" and other media such as PowerPoint and Word Documents.

\section{PENDAHULUAN}

Sistem pembelajaran daring merupakan implementasi pembelajaran jarak jauh. Pemerintah melakukan upaya pencegahan penyebaran COVID-19 pada bidang pendidikan dengan mengubah sistem daring. Karena itu, penelitian untuk mengetahui faktor-faktor yang mempengaruhi keefektifan sistem pembelajaran dari pada masa pandemi COVID-19 perlu dilakukan karena pembelajaran diperlukan dalam dunia pendidikan, yang diawali dengan proses interaksi antara peserta didik dan pendidik di ruang belajar. 
Sehubungan dengan hal di atas, pembelajaran mempunyai arti sebagai proses interaksi peserta didik dengan pendidik dan sumber belajar pada suatu lingkungan belajar. Pembelajaran merupakan bantuan yang diberikan pendidik agar dapat terjadi proses perolehan ilmu dan pengetahuan, penguasaan kemahiran dan tabiat, serta pembentukan sikap dan kepercayaan pada peserta didik. Pembelajaran bisa diartikan sebagai proses untuk membantu peserta didik agar dapat belajar dengan baik.

Gagne (1977) mengemukakan pembelajaran adalah seperangkat peristiwa-peristiwa eksternal yang dirancang untuk mendukung beberapa proses belajar yang bersifat internal. Menurut Gagne pembelajaran dimaksudkan untuk menghasilkan belajar, situasi eksternal harus dirancang sedemikian rupa untuk mengaktifkan, mendukung, dan mempertahankan proses internal yang terdapat dalam setiap peristiwa belajar.

Seperti yang sudah diketahui sebelumnya, pembelajaran selalu berpatokan dengan proses interaksi antara peserta didik dan pendidik (Maryam) menegaskan bahwa keterlibatan siswa dalam pembelajaran sangat penting sehingga peserta didik dapat belajar dan menguasai isi pelajaran hingga mencapai sesuatu objek yang ditentukan meliputi aspek kognitif, aspek afektif, dan aspek psikomotorik. Target belajar dapat diukur melalui proses belajar yang ditunjang oleh fasilitas belajar yang memadai seperti ruangan yang bersih dan nyaman serta sumber pengetahuan yang lengkap.

Proses belajar meliputi beberapa prinsip di antaranya, (a) perhatian dan motivasi atau gaining attention, (b) keaktifan, (c) keterlibatan langsung/pengalaman atau elicting performance, (d) pengulangan, (e) tantangan atau presenting the stimulus, (f) balikan dan penguatan atau providding feedback, dan (g) perbedaan individual atau assessing perfomance.

Keefektifan dalam sebuah proses pembelajaran tentu sangat ditentukam dalam belajar dan pembelajaran. Kefektifan pembelajaran adalah keberhasilan terhadap tujuan tertentu dengan menggunakan tindakan pendekatan, metode, ataupun strategi yang dimiliki oleh seorang guru.

Slavin (1994:310) menyatakan bahwa kefektifan pembelajaran ditentukan oleh empat indikator yaitu (1) kualitas pembelajaran yaitu seberapa kadar informasi yang disajikan sehingga siswa dengan mudah dapat mempelajarinya, (2) kesesuaian tingkat pembelajaran yaitu sejauh mana guru memastikan tingkat kesiapan siswa untuk mempelajari materi baru, (3) insentif yaitu seberapa besar usaha guru memotivasi siswa untuk mengerjakan tugas-tugas dan mempelajari materi yang diberikan, dan (4) waktu yaitu lamanya waktu yang diberikan kepada siswa untuk mempelajari materi yang diberikan.

Eggen dan Kauchak (1998:1) mengemukakan bahwa efektifitas pembelajaran ditandai dengan kefektifan pembelajaran adalah diawali dengan mengajukan pertanyaan, untuk mencapai tujuan belajar dalam waktu yang di tentukan. Karena itu, kefektifan pembelajaran meliputi pencapaian efektivitas guru dan siswa, pencapaian efektivitas kemampuan guru dalam pengelolaan pembelajaran kooperatif siswa, pencapaian ketuntasan belajar siswa dan respon siswa terhadap pembelajaran.

Sementara itu, proses pembelajaran ditingkat sekolah menggunakan sistem daring (dalam jaringan). Sistem pembelajaran daring adalah sistem pembelajaran tanpa tatap muka 
secara langsung antara guru dan siswa tetapi dilakukan melalui online yang menggunakan jaringan internet. Adanya sistem pembelajaran daring tersebut, guru selalu memantau pembelajaran, meskipun berada dirumah. Meskipun pembelajaran daring sudah ditetapkan selama masa pandemi ini, akan tetapi ada beberapa sekolah yang menjalankan sistem pembelajaran luring (luar jaringan).

Sistem pembelajaran ini berlaku di salah satu sekolah di Kabupaten Bantul tepatnya Kecamatan Pleret yakni sekolah SMP Negeri 3 Pleret. Dengan adanya pembelajaran daring terdapat keunikan yang dialami peserta didik seperti, dalam membantu peserta didik mendapatkan materi lebih banyak, peserta diidk semakin pintar menggunakan tekno-logi, peserta didik jadi merasakan pembelajaran homescholing, dan pembelajaran online bisa dilakukan dimana saja.

Adapun ciri pembelajaran daring, di antaranya (a) di bawah pengendalian langsung dari alat lainnya, (b) di bawah pengendalian langsung dari sebuah sistem, (c) tersedia untuk penggunaan segera atau real time, (d) tersambung pada suatu sistem dalam pengoperasiannya, dan (e) bersifat fungsional dan siap melayani.

Sedangkan, sistem pembelajaran luring yaitu proses belajar dan pembelajaran yang dilakukan secara tatap muka langsung antara peserta didik dan pendidik. Sistem pembelajaran luring yang dilaksanakan di SMP Negeri 3 Pleret ini dilakukan 2 kali tatap muka dalam seminggu. Pemberlakuan sistem belajar luring, hanya ditetapkan untuk mengumpulkan tugas dan mengambil tugas. Selebihnya tugas dan diskusi materi dilakukan melalui daring baik menggunakan aplikasi WhastApp, Google Clasroom, Google Formulir maupun Zoom dan aplikasi lainnya yang mendukung sistem belajar anak serta evaluasi dalam sebuah pembelajaran itu sangat perlu untuk mengulas materi agar mampu menentukan dari tingkat pemahamannya sendiri.

\section{METODE}

Metode yang digunakan dalam penelitian adalah deskriptif kualitatif. Hasil yang dianalisis akan diolah menjadi prosentase atau pertimbangan mengenai sistem belajar baik daring maupun luring.

Penelitian ini termasuk jenis penelitian deskriptif kualitatif. Penelitian ini berupaya nuntuk mempelajari masalah-masalah yang berkaitan dengan sistem pembelajaran daring. Penelitian ini menggunakan studi kasus eksplorasi yang bertujuan untuk mendapatkan informasi bagaimana pembelajaran selama pandemi COVID-19 dan apa kendalanya. Metode pengumpulan data menggunakan wawancara semi terstruktur yang dijadikan data primer. Sedangkan data sekunder berupa studi pustaka. Wawancara dilakukan secara semi terstruktur. Wawancara dilakukan menggunakan atau melalui alat komunikasi handphone melalui telepon langsung ataupun aplikasi komunikasi lainnya seperti WhatsApp. Wawancara dilakukan melalui telepon dimaksudkan untuk mendukung physical distancing yang diterapkan guna mencegah penularan COVID-19. Penelitian ini mewawancarai responden, di antaranya 2 orang guru serta 2 orang siswa.

\section{HASIL PENELITIAN}

\section{Efektivitas Daring dan Luring Menurut Siswa}

Hasil yang ditemukan dalam penelitian ini berdasar pada kualifikasi pendapat para siswa, terkait pembelajaran daring dan luring. Untuk itu, berikut hasil informasi data mengenai 
sistem belajar efektivitas pada proses daring dan luring di SMP Negeri 3 Pleret.

Berikut hasil yang diperoleh dari pendapat siswa mengenai belajar daring dan luring, penjelasannya sebagai berikut:

\begin{tabular}{ccc}
\hline Kelas & Belajar Daring & Belajar Luring \\
\hline 8 A & $40 \%$ & $60 \%$ \\
8 B & $35 \%$ & $65 \%$ \\
8 C & $20 \%$ & $80 \%$ \\
8 D & $22 \%$ & $78 \%$ \\
7 A & $37 \%$ & $63 \%$ \\
\hline
\end{tabular}

Dari data yang ditemukan, siswa cenderung mengalami keluhan selama proses pembelajaran daring. Mereka lebih senang jika belajar disekolah seperti sedia kala atau tatap muka (luring).

Banyak penelitian yang telah dilakukan oleh peneliti lain pada masa pandemi. Penelitian tersebut berisi tentang efektivitas pembelajaran berbasis daring ataupun luring. Penelitian terdahulu dilakukan guna mengetahui tingkat efektivitas pembelajaran yang dilakukan selama pembelajaran jarak jauh. Hasil penelitian terdahulu menunjukan hasil berupa pembelajaran jarak jauh tidak efektif. Hal tersebut cukup beralasan karena tidak ada kontrol secara langsung oleh guru.

Penelitian terdahulu yang dilakukan oleh Mega Berliana Yolandasari pada skripsi asal IAIN Salatiga pada skripsi yang berjudul "Efektivitas Pembelajaran Daring dalam Pembelajaran Bahasa Indonesia di Kelas II A MI Unggulan Miftahul Huda Tumang Cepogo Boyolali Tahun Pelajaran 2019/2020" misalnya. Penelitian yang telah dilakukan didapatkan hasil berupa: pembelajaran daring sangat tidak efektif. Hal tersebut didasarkan ungkapan dari peserta didik yang merasa pembelajaran daring justru membuat mereka tidak nyaman. Selain pandangan objektif dari para peserta didik tersebut, guru juga merasa dengan diadakannya pembelajaran secara daring membuat peserta didik menjadi terpaksa mengikuti pembelajaran. Selain itu, dengan pembelajaran jarak jauh sulit untuk membedakan apakah peserta didik memahami materi atau tidak. Jika diukur dengan skala ukuran, lebih banyak persentase tidak efektif daripada efektif.

Hasil berbeda diperoleh diperoleh dalam penelitian yang dilakukan oleh Intan Karlina Sari dan Suhandi Astuti yang berjudul "Efektivitas Pembelajaran Luring dan Daring Terhadap Hasil Belajar Tematik Siswa di Sekolah Dasar". Penelitian tersebut menyatakan bahwa pembelajara sencara daring lebih efektif digunakan pada materi tematik. Hal ini didasarkan pada test yang tlah dilakukan menggunakan uji beda rata-rata hasil belajar posttest (t-test) dalam penerapan metode pembelajara daring sebagai kelompok eksperimen 1 dan model pembelajaran luring sebagai kelompok eksperimen 2.

Dari dua perbandingan tersebut dapat ditarik kesimpulan bahwa pembelajaran daring memiliki kelebihan dan kekurangan. Jika dilihat dari jenis penelitian yang dilakukan pada anak-anakn sekilah dasar antara kelebihan dan keukarangan tersebut tidak terlalu terlihat signifikan. Hal ini beralasan karena pembelajaran di SD memiliki model tematik dan non tematik yang akan diajarkan. Dari keduanya memiliki kriteria serta standar yang berebdeda dalam pada hasil nelajar. Selain itu, pada pembelajaran anak- anak sekolah dasar masih berpola LOTS (Lower Order Thinking Skill) sehingga model belajara masih dapat disesuaikan dengan cara daring dan berpedoman pada materi yang diberikan. Berbeda dengan dengan pola pembelajaran di sekolah menengah yang sudah berpola HOTS (Higher Order Thinking Skill), pembelajaran harus benar-benar memperhatikan tingkat pemahaman serta pengaruh dari materi yang diberikan dengan perubahan perilaku pada peserta didik. Dengan demikian, penjelasan 
selanjutnya akan membahas mengenai efektivitas pembelajaran daring dan luring di tingkat SMP.

\section{Efektivitas Daring dan Luring Menurut Guru}

Hasil yang ditemukan dalam penelitian ini berdasar pada kualifikasi pendapat para guru, terkait pembelajaran daring dan luring. Untuk itu, berikut hasil informasi data mengenai sistem belajar efektifitas pada proses daring dan luring di SMP Negeri 3 Pleret.

Dari data yang ditemukan, guru menilai keefektifan belajar sebanyak $62 \%$ lebih memilih pembelajaran luring dan 38\% memilih pembelajaran dengan daring.

Setelah didapatkan bahwa siswa dan guru lebih memilih bahwa belajar luring lebih efektif dari pada belajar during, di bawah disajikan data persentase alasan ketidakefektivan pembelajaran during.

Dari data yang dianalisis bahwa alasan ketidakefektifan pembelajaran daring adalah susah sinyal 19\%, kouta internet $14 \%$ dan kurangnya pemahaman $67 \%$.

Berdasarkan hasil analisis, penelitian ini menunjukkan siswa dan guru menilai bahwa pembelajaran luring lebih efektif dari pada pembelajaran daring. Berdasarkan hasil wawancara dengan para siswa didapatkan ratarata $69.2 \%$ memilih pendapat bahwa pembelajaran luring lebih efektif dan sebanyak $30,8 \%$ siswa memilih pembelajarang daring lebih efektif. Dari hasil wawancara dengan guru didapakan data sebanyak 62\% guru berpendapat bahwa pembelajaran luring lebih efektif dan $38 \%$ guru berpendapat bahwa pembelajaran daring lebih efektif. Dengan demikian dapat dikatakan bahwa guru dan siswa lebih banyak berpendapat dan merasa bahwa pembelajaran luring lebih efektif daripada pembelajaran daring. Setelah didapatkan bahwa menurut siswa dan guru SMP
Negeri 3 Pleret pembelajaran luring lebih efektif dari pada pembelajaran daring maka didapatkan alasan dari ketidakefektifan pembelajaran daring adalah susah sinyal 19\%, Kouta Internet $14 \%$ dan kurangnya pemahaman 67\%. Berdasarkan analisis datanya artinya kurangnya kefektifan pembelajaran daring adalah karena pembelajaran daring dapat mengurangi tingkat pemahaman pembelajaran oleh pelajar.

Di daerah pelosok dan tidak mempunyai akses internet yang baik pelaksanaan pembelajaran daring menunjukkan kecenderungan yang berbeda. Dalam menyiasati kondisi ini, siswa yang tinggal didaerah yang sinyal internet lemah akan mencari wilayah-wilayah tertentu seperti perbukitan dan wilayah kecamatan untuk dapat terjangkau oleh akses internet. Hasil analisis data yang dilakukan oleh peneliti tentang keefektifan pembelajaran pembelajaran luring ini diperkuat dengan pendapat Hendrastomo (2008) bahwa ketersediaan akses internet sangat diperlukan dalam pembelajaran e-learning, karena karakteristik pembelajaran ini selalu menggunakan dan memanfaatkan jaringan internet sedangkan kecepatan akses jaringan internet di Indonesia relatif lambat, ketersediaan jangkauan yang terbatas dan harga kouta internet yang mahal sehingga menjadi hambatan bagi pembelajaran e-learning.

Kesulitan dalam layanan internet, sebagian siswa mengaku mengakses internet menggunakan layanan selular, dan sebagian kecil menggunakan layanan WiFi. Pembelajaran daring memiliki kelemahan ketika layanan internet lemah, dan intruksi guru yang kurang dipahami oleh siswa (Astuti, P., \& Febrian, F.,2019). Biaya akses internet juga sangat mahal. Siswa mengungkapkan bahwa untuk mengikuti pembelajaran daring, mereka harus mengeluarkan biaya cukup mahal untuk membeli kuota data internet. Menurut mereka, pembelajaran yang menggunakan aplikasi video telah menghabiskan banyak kuota data, 
sementara diskusi online melalui applikasi pesan instan tidak membutuhkan banyak kuota.

Walaupun penggunaan gawai dapat mendukung pembelajaran daring, tetapi ada dampak negatif yang perlu mendapat perhatian dan diantisipasi yaitu penggunaan gawai yang berlebihan. Mereka mengakui bahwa selain untuk pembelajaran, siswa juga menggunakan gawai untuk media social, game dan menonton youtube. Program belajar daring juga menimbulkan banyak kekhawatiran berbagai pihak karena lebih intensnya penggunaan gawai akan membuat siswa nantinya ketergantungan dan tidak bisa lepas sehingga memberikan dampak jangka Panjang yang lain. Banyak orang kecanduang gawai akibat menggunakannya secara berlebihan (Waslh, White \& Young, 2007). Perlu dikhawatirkan masuknya informasi yang menyesatkan dan tidak perhatian selama belajar akibat bermain media sosial (Siddiqui \& Singh, 2016). Selain itu, peserta didik yang kecanduan gawai memiliki masalah akademik dan sosial (Kwon et al., 2013). Peserta didik yang memiliki kecanduan gadget memiliki masalah emosional dan perilaku (Asif, A. R., \& Rahmadi, F. A., 2017).

Dari pendapat tersebut maka tidak heran bahwa ketersediaan jangkauan internet dan mahalnya kouta internet akan menjadi dua hambatan dalam pembelajaran karena tidak semua kondisi perekonomian siswa dapat mengapainya begitu pula kondisi susah sinyal yang mungkin diakibatkan kondisi geografis dan pembangunan pemerintahan yang tidak merata. Kondisi tersebut rasanya tidak akan terselesaikan dengan solusi dari satu pihak saja dan bukan permasalahan yang dapat selesai dalam sekejap.

Bahan ajar biasa disampaikan dalam bentuk bacaan yang tidak mudah dipahami secara menyeluruh oleh mahasiswa (Sadikin, A., \& Hakim, N., 2019). Siswa banyak ber- anggapan bahwa materi dan tugas tidak cukup karena perlu penjelasan secara langsung oleh guru. Garrison \& Cleveland-Innes (2005) dan Swan (2002) melaporkan bahwa kelas yang gurunya sering masuk dan memberikan penjelasan memberikan pembelajaran lebih baik dibandingkan kelas yang gurunya jarang masuk kelas dan memberikan penjelasan.

Pembelajaran during memberikan dampak negatif yang dirasakan seperti guru dan peserta didik tidak dapat memberi feedback secara cepat, pemahaman anak terhaap suatu materi kurang mendalam, penilaian hanya dilakukan melalui penilaian hasil saja guru tidak dapat melihat proses anak tersebut maka akan kurang juga dalam mendeteksi kekurangan anak. Guru tidak dapat mengontrol anak saat memberikan penjelasan anak juga tidak semuanya mau aktif dalam pembelajaran during meskipun tekanan psikologis dari teman atau guru secara langsung tidak ada tapi ada juga yang beranggapan bahwa tekanan psikologis untuk aktif dalam pembalajaran during juga ada.

Lokasi siswa dan guru yang terpisah saat melaksanakan pembelajaran during menyebabkan guru tidak dapat mengawasi secara langsung kegiatan siswa selama proses belajar mengajar. Tidak ada jaminan bahwa siswa sungguh-sungguh dalam mendengarkan ulasan dari guru. Szpunar, Moulton, \& Schacter, (2013) melaporkan dalam penelitiannya bahwa mahasiswa menghayal lebih sering pada perkuliahan daring dibandingkan ketika kuliah tatap muka. Oleh karena itu disarankan pembelajaran daring sebaiknya diselenggarakan dalam waktu tidak lama mengingat mahasiswa sulit mempertahankan konsentrasinya apabila perkuliahan daring dilaksanakan lebih dari satu jam (Khan.,2012).

Diskusi merupakan jantung hati dari keseluruhan batang tubuh suatu artikel ilmiah. Fungsinya adalah untuk menjawab pertanyaan penelitian sebagaimana telah diajukan pada 
Bagian Pendahuluan dan temuan pada hasil penelitian. Secara umum, tujuan utama pada bagian diskusi, yaitu memberikan penjelasan mendalam terkait temuan-temuan penelitian, membuat interpretasi dan/atau pendapat, dan menjelaskan implikasi penelitian, serta saran untuk penelitian lanjutan.

Arah diskusi yang baik, yaitu selalu connect dengan uraian yang telah disebutkan pada bagian pendahuluan, utamanya untuk mejawab rumusan masalah, hipotesisnya (jika ada), dan disertai kajian literaturnya. Patut untuk dicermati bahwa hal ini bukan berarti anda "mengulang" hal-hal yang disampaikan pada bagian pendahuluan, melainkan memberikan penegasan kepada pembaca terkait bagaimana pembaca memahami masalah dalam penelitian yang dilakukan. Untuk menyampaikan "pesan" penelitian dengan jelas, alur diskusi dibuat terstruktur dan logis. Diskusi harus didukung oleh kajian mendalam terhadap hasil-hasil penelitian, baik itu dalam rangka menguatkan atau membenahi kajian yang sudah ada, atau memunculkan kajian baru.

\section{SIMPULAN}

Berdasarkan hasil penelitian dan pembahasan diatas, maka diperoleh kesimpulan bahwa pada penelitian ini siswa dan guru menilai bahwa pembelajaran luring lebih efektifdari pada pembelajaran luring. Hal ini di tunjukkan dari hasil wawancara dengan para siswa didapatkan rata-rata $69.2 \%$ memilih pendapat bahwa pembelajaran luring lebih efektif dan sebanyak 30,8\% siswa memilih pembelajaran during lebih efektif. Selanjutnya dari hasil wawancara dengan guru didapakan data sebanyak $62 \%$ guru berpendapat bahwa pembelajaran luring lebih efektif dan 38\% guru berpendapat bahwa pembelajaran daring lebih efektif.

Alasan dari ketidakefektifan pembelajaran daring menurut siswa dan guru SMP Negeri 3 Pleret adalah susah sinyal 19\%, Kouta Internet $14 \%$ dan kurangnya pemahaman $67 \%$. Selain itu Lokasi siswa dan guru yang terpisah saat melaksanakan pembelajaran daring menyebabkan guru tidak dapat mengawasi secara langsung kegiatan siswa selama proses belajar mengajar. Tidak ada jaminan bahwa siswa sungguh-sungguh dalam mendengarkan penjelasan dari guru, sehingga pembelajaran during dapat mengurangi tingkat pemahaman pembelajaran oleh pelajar.

\section{DAFTAR PUSTAKA}

Ali Sadiki dkk. (2020)." Pembelajaran Daring di Tengah Wabah Covid-19. Jurnal Ilmiah Pendidikan Biologi, 6(2) 214-224.

Asif, A. R., \& Rahmadi, F. A. (2017). "Hubungan tingkat kecanduan gadget dengan gangguan emosi dan perilaku remaja usia 11-12 tahun" (Doctoral dissertation, Faculty of Medicine).

Aunurahhman.(2016). "Belajar dan Pembelajaran.” Bandung: Alfabeta

Eggen \& Kauchak.(1998). Metdhos for Teaching. Jakarta: Pustaka Pelajar.

Firman, F., \& Rahayu, S. (2020_. "Pembelajaran Online di Tengah Pandemi Covid-19". Indonesian Journal of Educational Science (IJES), 2(2), 81-89. 
Gagne, R.M. (1977). “The Conditions of Learning”. New York: Holt Rinehart and Winston.

Garrison, D. R., \& Cleveland-Innes, M. (2005). "In Online Learning: Interaction Is Not Enough."

Hendrastomo, G. (2008). "Dilema dan Tantangan Pembelajaran E-learning 1 (The Dilemma and the Challenge of”. Majalah Ilmiah Pembelajaran, 4, 1-13.

Kwon, M., Lee, J. Y., Won, W. Y., Park, J. W., Min, J. A., Hahn, C., ... Kim, D. J. (2013). "Development and Validation of a Smartphone Addiction Scale (S8AS)".

L, Idrus. (2019). "Evaluasi Dalam Proses Pembelajaran”. Jurnal Manajemen Pendidikan Islam, 9(2) hal.162.

Majid, Abdul. (2013). Strategi Pembelajaran. Bandung: PT. Remaja Roskadaya.

Maryam, Siti.(2019) "Life Map to Improve Student Engagement Contents in Writing Learning for Strengthening Contents Students ' Character." Educare: International Journal for Educational Studies, vol. 11, no. 2, 2019, pp. 39-56, http://journals.mindamas.com/index.php/educare/article/view/1245.

Sadikin, A., \& Hakim, N. (2019). "Pengembangan Media E-Learning Interaktif dalam Menyongsong Revolusi Industri 4.0 Pada Materi Ekosistem Untuk Siswa SMA.” BIODIK, 5(2), 131-138.

Sadikin, A., Johari, A., \& Suryani, L. .(2020. "Pengembangan multimedia interaktif biologi berbasis website dalam menghadapi revolusi industri 4.0." Edubiotik: Jurnal Pendidikan, Biologi Dan Terapan, 5(01), 18-28.

Sari, Intan Karlina, \& Astuti Suhandi. (2021). "Efektivitas Pembelajaran Luring dan Daring Terhadap Hasil Belajar Tematik Siswa di Sekolah Dasar". Jurnal Ilmu Pendidikan. Vol 3 Tahun 2021.

Siddiqui, S., \& Singh, T. (2016). "Social Media its Impact with Positive and Negative Aspects". International Journal of Computer Applications Technology and Research.

Slavin. (1994). Model Pembelajaran Cooperatif Script. Jakarta: Airlangga

Swan, K. (2002). "Building Learning Communities in Online Courses: the importance of interaction”. Education, Communication \& Information.

Szpunar, K. K., Moulton, S. T., \& Schacter, D. L. (2013). "Mind wandering and education: From the classroom to online learning." Frontiers in Psychology.

Yolandasari, Mega Berliana. (2020). "Efektivitas Pembelajaran Daring dalam Pembelajaran Bahasa Indonesia di Kelas II A MI Unggulan Miftahul Huda Tumang Cepogo Boyolali Tahun Pelajaran 2019/2020”. (Skripsi): IAIN Salatiga. 